\title{
Epidermal Growth Factor Receptor Measurement
}

National Cancer Institute

\section{Source}

National Cancer Institute. Epidermal Growth Factor Receptor Measurement. NCI

Thesaurus. Code C112273.

The determination of the amount of epidermal growth factor receptor present in a sample. 